\title{
Além do que os olhos podem ver
}

Desde sua criação, o cinema fascina e inquieta. Ao início do século XX, acreditava-se que o filme tinha tamanho poder de influência sobre seus espectadores que seria capaz de convencê-los a sustentar ou derrubar governos, aceitar ou negar ideias, adotar ou abandonar comportamentos, entre outros. Diante desse quadro, conforme Marc Ferro destaca um artigo pioneiro, muitos governos estabeleceram leis e instituições para controlar e/ou cooptar a produção cinematográfica ${ }^{1}$.

Exageros à parte, tais concepções ainda hoje fazem parte do conjunto de debates a respeito das relações entre o cinema e sociedade. Em verdade, é mais correto utilizarmos ambos os termos no plural, uma vez a chamada 'sétima arte' espalhou-se pelo mundo, desdobrando-se em uma série de indústrias e movimentos que só podem ser compreendidos quando analisados à luz de um determinado contexto histórico e considerando-se as relações sociais existentes. O presente dossiê busca se debruçar sobre algumas dessas candentes preocupações.

Alexandre Busko Valim classifica o cinema, simultaneamente, como prática social e gerador de práticas sociais - "ou seja, o cinema, além de ser um testemunho das formas de agir, pensar e sentir de uma sociedade, é também um agente que suscita certas transformações, veicula representações ou propõe modelos"2 ${ }^{\prime 2}$ Inspirado nos apontamentos de Ciro Flamarion Cardoso, o autor defende que, para que possamos compreender a trajetória e o impacto de um filme, precisamos analisá-lo a partir do chamado Circuito Comunicacional. Trata-se de um sistema composto por três esferas inter-relacionadas que abrangem, respectivamente, os processos de produção, circulação e recepção de uma produção cinematográfica em uma determinada sociedade e em um dado contexto.

\footnotetext{
${ }^{1}$ FERRO, Marc. O filme, uma contra-análise da sociedade. In: FERRO, Marc. Cinema e história. Rio de Janeiro: Paz e Terra, 1992, p. 79-115.

${ }^{2}$ VALIM, Alexandre Busko. História e cinema. In: CARDOSO, Ciro Flamarion; VAINFAS, Ronaldo (orgs). Novos domínios da História. Rio de Janeiro: Elsevier, 2012, p. 283-300.
} 
A esfera da produção diz respeito, justamente, aos elementos que influenciam a produção de uma obra cinematográfica. Como bem destaca Pierre Sorlin, estamos lidando com um todo complexo de questões políticas, econômicas, sociais e ideológicas, uma vez que todo filme é fabricado conforme as condições materiais existentes ${ }^{3}$. Relações de trabalho, negociações entre os estúdios e outras instituições, códigos estéticos e convenções de linguagem dominantes, a atuação da censura, aparatos tecnológicos disponíveis e orçamento são algumas dos elementoschave para entender esse contexto.

A esfera da circulação, por sua vez, diz respeito às estratégias de distribuição e aos locais em que um determinado filme foi exibido. Trata-se, pois, de se conhecer o funcionamento dos mercados de distribuição e exibição cinematográficos, bem como, as relações que se estabelecem entre os estúdios e as demais instituições sociais para potencializar ou restringir a circulação de uma determinada obra. $O$ estudo desse campo dirige também grande preocupação ao material publicitário utilizado na divulgação de um título.

Por fim, a esfera da recepção constitui o maior desafio do Circuito Comunicacional. Se é inegável que toda equipe que produz um filme tem intenções e que o cinema tem potencial para influenciar seus públicos; é igualmente difícil aferir o impacto de uma produção cinematográfica sobre um espectador ou um determinado público. Para Janet Staiger, o contexto é o fator mais determinante na leitura de qualquer texto cultural, pois é a partir de sua relação com o mundo que cada indivíduo adquire conhecimentos que lhe permite identificar e interpretar as convenções estéticas presentes nas obras cinematográficas. Assim, fatores como classe, gênero, raça, posição política e experiências pessoais, entre outros interferem no vínculo que o espectador estabelece com um filme ${ }^{4}$.

Par além das questões elencadas por Staiger, é importante romper com a ideia do público como o elemento passivo dessa equação, que consome tudo o que o cinema the apresenta sem questionar. O espectador é um agente histórico, capaz de se posicionar diante dos valores

\footnotetext{
3 SORLIN, Pierre. Sociología del Cine: La Apertura para la Historia de Mañana. México, D. F.: Fondo de Cultura Económica, 1985.
}

4 STAIGER, Janet. Introduction. In: STAIGER, Janet. Perverse Spectators: The Practices of Film Reception. Nova Iorque/Londres: New York University Press, 2000, p. 1-7. 
veiculados por um filme e, até mesmo, negá-los. A dinâmica complexa que se estabelece entre a "interpretação que os responsáveis pelo filme almejavam" e "a leitura realizada" pelo público é apenas um dos elementos que torna a esfera da recepção a mais caudalosa de todo o circuito comunicacional.

Nesse sentido, consideramos que o cinema é, concomitantemente, uma indústria, uma forma de arte, uma forma de entretenimento e uma mídia capaz de veicular representações, valores e ideias que vão além do mero divertimento. Devido à sua complexidade, trata-se de um objeto cada vez mais estudado por diferentes campos das ciências. Em todo o Brasil, grupos de pesquisa se debruçam sobre o conjunto de relações entre cinema e sociedade a partir de diferentes abordagens teórico-metodológicas. O presente dossiê contou com a participação de autores do Núcleo de Estudos de História e Cinema da Universidade Federal de Santa Catarina (NEHCINE-UFSC), cuja atuação é pautada pela História Social do Cinema, corrente cujas bases remontam ao materialismo histórico, à História Social britânica e à Psicologia Social francesa.

Em seu artigo, Ana Crhistina Vanali busca resgatar a importância dos documentários produzidos durante a Guerra do Contestado, analisando sua recepção na capital paranaense e as imagens a respeito dos revoltosos. Já Celso Fernando Claro de Oliveira analisa a importância da paisagem na narrativa do clássico "As Vinhas da Ira" (1940), procurando compreender a organização do espaço de ação fílmico conforme as convenções estéticas e linguísticas da Hollywood da época.

Rodrigo Candido da Silva, por sua vez, debate a emergência do cinema Blockbuster hollywoodiano à luz das políticas implementadas pelo governo de Ronald Reagan e das mudanças na constituição do público estadunidense entre os anos de 1970-1980. A fim de discutir as relações Brasil-Estados Unidos durante a Segunda Guerra Mundial, Nayara Régis Franz trabalha com a produção e a recepção da animação "Fantasia" (1940), título produzido pelos estúdios Disney como ferramenta para implementar a Política de Boa Vizinhança no continente americano.

Esperamos que as contribuições aqui prestadas sejam de grande valia para os pesquisadores mais experimentados e que possam também despertar o interesse por parte de estudantes que pensam em enveredar pelos estudos das relações entre cinema e sociedade. 
Celso Fernando Claro de Oliveira

Ana Crhistina Vanali 